\title{
MORE OR LESS HUMAN: RESILIENCE, VULNERABILITY, AND LOVE IN NEOLIBERAL TIMES
}

\author{
Kit Dobson \\ Mount Royal University
}

\begin{abstract}
This article examines the question of what it means to be human in a post-human context. Tackling the quandary of whether there might be such a thing as post-human love, the article turns to recent trends in affect theory and critical approaches more broadly in order to understand what is at stake in developing a theoretical understanding of love itself. These issues are, in turn, analyzed through Dionne Brand's 2014 novel Love Enough. This analysis strengthens the article's argument that fictions of globality produced in Canada play a role in challenging the ongoing reconsolidation of the normative modes of human embodiment enforced under neoliberal forms of governance.
\end{abstract}

KeYwORds: globality, affect theory, post-humanism, love, Dionne Brand.

\author{
MÁS O MENOS HUMANO: RESILIENCIA, VULNERABILIDAD \\ Y AMOR EN TIEMPOS NEOLIBERALES
}

\section{ResUmen}

Este artículo intenta responder la pregunta de qué significa ser humano en un contexto posthumano. Al examinar el dilema de si podría haber algo como el amor poshumano, el artículo trata más ampliamente el pensamiento reciente sobre la teoría del afecto y el pensamiento crítico para comprender lo que está en juego en el desarrollo de una interpretación teórica del amor en sí mismo. Estos problemas, a su vez, se analizan por medio de la novela Love Enough de Dionne Brand, publicada en 2014. Este análisis refuerza el argumento del artículo de que las ficciones de globalidad producidas en Canadá juegan un papel en el desafío a la reconsolidación actual de los modos normativos de representación humana aplicados bajo las formas neoliberales de gobierno.

Palabras Clave: globalidad, teoría del afecto, post-humanismo, amor, Dionne Brand. 
This essay is an outcome of an urgent project in the contemporary moment of new political and social barriers to movement and to participation in something like a democratic order. It is a moment in which I am interrogating Canada's role in current global shifts through literary texts and, in particular, through Dionne Brand's 2014 novel Love Enough. As I witness new, disturbing political alignments formulating themselves internationally, I find myself wondering once again about the ways in which the bodies of human animals are organized, about how that organization continues to prioritize some bodies ahead of others, and about whether self-organization through a revitalized concept of love might play a role in contesting oppression. Canadian fictions of globality play a role, I argue, in interrogating the ongoing reconsolidation of a normative mode of human embodiment that this essay seeks to challenge. My subtitle, "resilience, vulnerability, and love in neoliberal times," is a signal of, I hope, a shift in the direction of my recent work toward affirmation and constructive ways of finding and building communities in spite of the odds. The question that guides this thinking, and at which I will arrive in full by the end of this piece is as follows: is there such a thing as post-human love? It may sound like a simple question, but I contend that it is a difficult one, and one with high stakes, too.

In this essay, I am interested in the ways in which the category of the human can be used as a label of discursive control, or as a way to wield power in a global order that uses power with perhaps more firmness than ever. What power does the concept of the human hold in a world of new walls and barriers? In another article linked to this one, I quote trans writer and performer Ivan E. Coyote, who, in their 2014 collaborative project with Rae Spoon, entitled Gender Failure, writes the following: "I get really tired of being mistaken for a monster" (210; see Dobson, "Untold"). Who is mistaken for a monster? When and under what circumstances? What does that mis-takenness mean? The word "monster," etymologically, comes to English from Latin via French: a monstrum is a divine omen or a sign, something out of the ordinary. The word's meaning has shifted over time to signify an unusual, non-human animal, something monstrous, negative, shunned. The term is linked to the word "demonstrate," as well, for to demonstrate is to reveal an omen or a sign. What, then, does it demonstrate to be monstrous? What does Ivan E. Coyote's supposed monstrosity reveal, demonstrated as it is in their case in each and every gender binary space -spaces into which they do not and cannot easily fit? And what, in turn, is revealed any and every time that the body of a human animal (or indeed any animal) is marked as monstrous? The trope of perceiving oneself to be somehow less-than-human is remarkably common in contemporary writing. What, discursively, is at stake in demonstrating which humans are humans -and which humans are somehow less, other, or monsters?

The insights of people working in the terrain of post-humanism might quickly note, as Rosi Braidotti does, that the label of "human" is one that has its own history, one that indicates many things to us that are not neutral. For Braidotti, the term is definitively tied to the European Enlightenment, and hence carries a great deal of euro-centric baggage. To imagine that the "human" as a straightforward term in a global order is, following Braidotti's logic, highly suspect. She documents 
how the term goes right back to Leonardo da Vinci's Vetruvian Man, and shows that da Vinci's and his contemporaries' assessments of what constituted the human, or the human norm, continues to underwrite what it means, today, to be human. When Frantz Fanon writes, then, in Black Skin, White Masks (1967), that "the black is not a man" (8), he observes a troublesome norm, a norm that the concept of the human can indicate: the term "man" has been defined, a priori, to exclude a man who is black. And when, in Red Skin, White Masks (2014), Glen Coulthard builds on Fanon's thinking in order to critique the politics of Indigenous recognition, arguing that recognition by the state continues to rely on the antecedent settler community in order to simultaneously grant and delimit Indigenous selfhood, he notes in the process precisely how controlling the dominant concept of the human can be. He suggests how the settler human, which has granted itself the status of determining who is human enough to perform acts of recognition, then uses the concept in order to limit Indigenous bodies at the very same moment at which recognition occurs. When such Indigenous bodies seek to align themselves outside of the liberal, capitalist order imposed upon the northern communities that Coulthard studies, they are deemed to be other, lesser, not-quite-fully human.

This essay, then, attempts to work through the problematics of the human for the bodies of human animals operating in Canada today and to push back against the restrictions that the term can impose, even to the point of embracing a post-human articulation of the body. This situation, in my view, is one that is vital. While it is a potentially vast topic, I limit myself in my thinking to specifically how the trope of the less-than-human operates in texts, and to how, in turn, one might respond to that trope. This line of reasoning leads me to the question of love in Dionne Brand's Love Enough, but requires a series of other routes in order to get to that point. When Ivan E. Coyote notes that they are routinely taken to be "a monster" rather than a human, for instance, they note exactly where the limitations to a politics of recognition might lie and begin to suggest what lies beyond the human as we have so far known it. In their case, the limits of recognition fail Coyote at the moment when gender dimorphism is not only expected, but also enforced through mechanisms like segregated washrooms and government documentation systems. In other cases, the boundaries of the body might be enforced in other, still violent manners. In her study TransCanadian Feminist Fictions: New Cross-Border Ethics (2017), Libe García Zarranz writes of the War on Terror's "climate of fear" as follows: in this environment, she states, "endless references to toxic bacteria, virus, disease, contagion, and suspicious liquids have permeated both political and cultural discourse as a strategy to manage those disposable, and often racialized, populations, such as the refugee or the migrant", in other words, those "who do not conform to normative conceptualizations of the subject" (22). Bodies that fall outside of the normative, she argues, are policed in a variety of ways, all of which serve to hierarchize and prioritize more normative bodies ahead of others in a necropolitical strategy of determining late capitalism's winners and losers. In invoking this contemporary climate, García Zarranz echoes others, like Elizabeth Povinelli, who argues that, under neoliberalism, "any form of life that is not organized on the basis of market values is characterized as a potential security risk" (22). In this neoliberal climate, 
the priority falls upon organizing bodies in terms of the market, and then in harshly excluding those bodies that are deemed to be less market-worthy. William E. Connolly puts the situation as follows: "neoliberalism is a form of biopolitics that seeks to produce a nation of regular individuals, even as its proponents often act as if they are merely describing processes that are automatic and individual behaviour that is free" (59). What happens, however, to those bodies that cannot be produced as "regular individuals"? What about us "irregular" individuals? What of those bodies that lie distinctively, even defiantly, outside of such a "regular" economy? Therein lies the core of my investigation.

The Canadian framework in which I write this article -and within which this special issue is couched-importantly signals Canada's insider / outsider status in a global neoliberal politics headed by a faltering United States; it is, I find, fertile ground for theorization. While I concerned myself previously with developing a transnational framework for my studies, this new work shifts the field (see Dobson, Transnational). I concern myself in different ways here with four particularly difficult, intersecting, axes of oppression: first, I concern myself with the gendered body, and in particular statements like Ivan E. Coyote's that demonstrate ongoing dehumanization, even in the wake of a "benevolent" nation-state that has sought to recognize and include genders beyond the binary. Second, I am concerned with migration; both of these issues firmly enter into Brand's novel, as well as in my other investigations (see Dobson, "Neoliberalism"). Third, I consider the ways in which the technologically post-human or cyborg body might rescript what it means to live in late capitalism. Here, literary investigations like Larissa Lai's Automaton Biographies (2009) and Douglas Coupland's Player One (2010) extend how the human body has been thought up to this point, all the while showing the limitations to how the post-human body exists in relation to the marketplace that seeks to contain it (see Dobson, "Dystopia"). ${ }^{1}$ Finally, I retain an ongoing concern with Indigenous discourses, such as Lee Maracle's book Talking to the Diaspora (2015), which seeks acknowledgment of the ways in which diasporic bodies in Canada - a category that Maracle uses to include all non-Indigenous Canadians - have attempted to hijack the notion of the human in order to place Indigenous bodies outside of or adjacent to it.

In her book Giving an Account of Oneself (2003), Judith Butler argues that "life might be understood as precisely that which exceeds any account we may try to give of it" (43). Resisting the narratological, as well as teleological directives placed upon the body might be one way to reconceive of the human, or even to conceive beyond the human. Elizabeth Povinelli, in her work, looks for what she terms "spaces of otherwise" (6), thinking that, in a slightly different vein, Cherokee scholar Daniel Heath Justice echoes in his new monograph, Why Indigenous Literatures Matter (2018), when he asks readers to "imagine otherwise". Conceiving beyond the human as we have thus far known it, however, presents us with myriad new challenges.

\footnotetext{
${ }^{1}$ One might similarly read the convergence of the characters Bedri and Germain with the technology of the automobile in Brand's Love Enough.
} 
Braidotti notes that technological capitalism is post-anthropocentric in that it seeks to include all aspects of human life within the marketplace, hence de-prioritizing human life in the manner upheld by Enlightenment discourse. This de-prioritization is undertaken in the name of exploiting the body for new, market-driven purposes, and may well impede the flourishing of human animals. At the same time, Braidotti observes that the challenge "consists in grabbing the opportunities offered by the decline of the unitary subject position upheld by Humanism" (54). How might the human be resisted, or even overthrown, in a manner that does not align with the dictates of technologically driven market forces? How, in other words, might a careful dismantling of the human be used not to magnify the monstrosity of the market-embedded body, but rather to create possibilities for rupture and renewal?

My provisional answer to many of the bleak portrayals of what it means to be less-than-fully human, or what it means to be unrecognized as a sufficient form of life by the dominant forces governing today, is to turn to the concept of love. While we might seek this concept in many places, I turn here to Dionne Brand's novel Love Enough. I argue that the novel stages particular forms of love in order to locate the affective elements needed to confront injustice and maintain political attachments. In order to do so, I first turn to the anti-racist feminist thinker Sara Ahmed, who is deeply suspicious of love. In The Cultural Politics of Emotion (2004), one of the most powerful analyses of the book arrives when Ahmed notes the ways in which hate groups in online and other environments habitually declare themselves to be based upon love. So, for instance, she notes the ways in which racist Aryan organizations declare themselves to be, in fact, groups devoted to the love of a so-called traditional society that is perceived as being under threat. According to the logic that she analyzes, it is not so much that racist groups hate particular minorities, but, rather, in their view it is because they love a supposed historically pure version of their country that they seek to expel minority groups. Ahmed notes not simply that this declaration is a perverse reversal of what we might understand love to be, but also that such moments reveal that the logic of love can be used to exclude as much as to include different bodies. Love, in other words, can be dangerous, and so I hope to use the term advisedly in considerations of globality and its discontents. In The Promise of Happiness (2010), Ahmed focuses upon the ways in which discourses of happiness (of which love is perhaps the most obvious example) are used to reproduce social norms: the happy housewife, the happy family, and so on. She identifies herself instead with figures whom she calls the feminist killjoy, the unhappy queer, and the melancholic migrant, and argues against happiness because of its frequent complicity with violent forms of normativity.

Indeed, there is a growing recent academic literature on questions of love that can open up what might be at stake in Brand's novel. A range of thinkers has recently considered the question of love, from Alain Badiou and Michael Hardt to bell hooks and Lauren Berlant. For Badiou, contemporary concepts of love tend to be very shallow, limited to concepts of romance and marriage scripts, when in fact it is something that philosophy needs in order to innovate, to find the spaces in which we might continue to hope (11). In this context, he asserts, we need a new conception of love, one that is "an existential project: to construct a world from a 
decentered point of view other than of my mere impulse to survive or re-affirm my own identity" (25). This love is risky: it is, in Badiou's own sense, an event, and it involves the possibility of the losses that we may have experienced as lovers. Yet love, for Badiou, is a means of producing a truth; it is a truth procedure (38). As such, "to love is to struggle" (104): one loves because one seeks the possibility of the construction of a truth, a truth that is outside of the solipsistic, individualistic self of liberalism: love is, indeed, a space of possibility. ${ }^{2}$ For Michael Hardt, similarly, love contains within it the possibility of change. He writes that "a political love must be a revolutionary force that radically breaks with the structures of social life we know, overthrowing its norms and institutions [...] it must provide mechanisms of lasting association and stable social bonds" (6). This love is non-normative, embracing of difference and the nomadic Deleuzian structures that Hardt invokes; he wishes for new institutions of love that facilitate and organize "the return of joyful, beneficial social encounters" (12) in lieu of the stasis that neoliberal normativities generate. As such, to love is to open and expand beyond the world as we have known it and it is a key to reconceiving how we might relate to the global flows of late capitalism.

Bell hooks' conception of love is, in contrast, a very broad one. hooks notes that social justice movements tend to emphasize a version of a love ethic (xix) and she posits that such an ethic can inform our intellectual endeavours as well. In this context, she suggests that "we would all love better if we used it as a verb" (4), in the context of lives of becoming that require a forgiving heart if we are to make change. As such, she suggests that "there can be no love without justice" (19; see 30), and the tandem of love and justice permeate her thinking. She argues that contemporary capitalism is incompatible with many forms of love (72), and, as such, suggests that love may, indeed, maintain a revolutionary power. Quoting the monk and writer Thomas Merton, she goes on to argue that we cannot be fully human without loving (75-76). To love in a revolutionary way is to break the bonds of inhuman domination, to wrest autonomy from the instrumental logic of late capitalism, and, as such, to become a posthuman subject shedding the skin of liberal humanism. It is to move away from normative ideals and to dwell in possibility.

Lauren Berlant, though, is less optimistic and will lead us back to Brand and, in turn, Ahmed and my opening question in this piece. "[W]ho is to say," Berlant writes, "whether a love relation is real or is really something else, a passing fancy or trick someone plays (on herself, on another) in order to sustain a fantasy?" (7). Love, Berlant notes, is already circumscribed; it has become "a way of imagining particular utopias of gender and sex" defined by western mass culture (17). Berlant sees love as structured by melancholia, by an unshifting attachment to an object that may provide pleasure as part of the ego's search for ideal objects to replace forms of primary loss. These narratives, too, have been subsumed to the narratives of capital:

2 One book that is very much worth a further discussion elsewhere, and that falls under that umbrella of liberal thinking, is Martha Nussbaum's Political Emotions: Why Love Matters for Justice (2015), published by Belknap Press. 
"the reduction of life's legitimate possibility to one plot", the plot of the bourgeois family analyzed by Marx, Berlant argues, "is the source of romantic love's terrorizing, coercive, shaming, manipulative, or just diminishing effects -on the imagination as well as on practice" (87). But here an important distinction is key: Berlant opens up space between love and what she terms "romantic love," leaving the possibility that there may be more to love than meets the eye. ${ }^{3}$ She concludes by noting that "despite everything, desire / love continues to exert a utopian promise to discover a form that is elastic enough to manage what living throws at lovers" (112). In spite of severe doubts, then, love remains as a concept that recent theorists whose thinking rests within the frames of globality do not seem to be able to shake; indeed, it may be one of the few concepts or affects that maintains a sense of constructive possibility.

It is at this juncture that Dionne Brand stages her intervention with the novel Love Enough. This novel reflects, I think, critic Paul Barrett's recent claim in his book Blackening Canada (2015) that Brand's work rewrites losses and absences "as containing the conditions of possibilities for new subjectivities" (27). Brand's lengthy history of writing poetry, fiction, and non-fiction about diasporic and queer bodies, in this novel, seems to move very clearly toward an inquiry into the intertwined political and personal possibilities of love. The novel can be described as a series of interconnected character vignettes, each of which touch, in one way or another, on the question of love. There are, in essence, three linked dyads of characters. First is the dyad of June and Sydney, middle-aged lovers of very different political stripes; second is the friendship between two young men, Bedri and Germain; and third is the friendship between two young women, Lia and Jaspreet. Other characters - family, lovers - touch these three dyads, yet they remain the core of the novel. The first dyad, on which I will be focusing here, consists of the relationship between practical, pragmatic Sydney, who works at a retail outlet in Barrie, Ontario, north of Toronto, and the political, nostalgic June, who works at an archive for women's history in Toronto. The key question for these two lovers is whether Sydney's pragmatism suffices for June, who wishes only to receive "one embrace each day and one kindness each week" from her lover (113-14).

Early in the novel, Sydney and June argue during a run along the lakeshore. During this run, the argument, and the subsequent silence that follows upon it, the narrative reasons that love is what counters the toxic effects and affects of the world. Brand writes:

No argument in the world is ever resolved. Resolving would suggest some liquid in which arguments could be immersed, perhaps love. But it must be love enough. The consistency of the mixture would have to be a greater portion of love. So many decilitres of love to dissolve so many millilitres of the other stuff. And the trouble is, this "other stuff," this toxic material, is sometimes flammable. These other ingredients are random and personal, like childhood or desire and they don't necessarily

${ }^{3}$ A future conversation might also analyze Luce Irigaray's The Way of Love (2002), translated by Heidi Bostic and Stephen Pluhàcek, and published in 2002 by Continuum, in this context. 
mix well with love. Love is not as durable or pliable as one is led to think anyway. Love can be indefinable all on its own. (5)

That love is required in greater proportions than the toxic affects around us, no doubt, reflects the world that we inhabit. It is in this context that Sydney and June later find themselves arguing in the morning over something half-heard on the radio: June hears the Canadian Broadcasting Corporation radio announcer stating that the City of Toronto has plans to send a hundred musicians to the intersection of Jane and Finch in an act of musical compassion and beauty, while Sydney immediately believes that the radio has claimed that it will send a hundred police officers, given that neighbourhood and intersection's long reputation for being troubled. Even though June turns out to be right, the question of how to deal with a world of toxic affects remains unresolved: we may celebrate, as I do, the invocation of music, but is that act of love merely a drop in a sea of toxins? Or is it, in some sense, love enough?

Such questions animate June and Sydney's relationship. June's history is one that is filled with lovers, many of them refugees and revolutionaries thrown into Toronto by the global flows of colonization. This history has left her with a changed vocabulary, one that leads her to hesitate to ever use the word love. Her experiences have made her wonder if, as lovers, we expect our "own reflection in the lover's face" (8), every love becoming instead a misrecognition. As such, she is not quite in love with Sydney, and is vague about her past, about her different lovers -Tamil, Nicaraguan, Chilean. She refuses many of the conventions of love and intimacy and finds, notes the narrator, that "it's difficult to say anything conclusive about love" (55). Love changes; it exists in time. In the 1970s and 80s, for June, it meant sleeping with refugees (56), but, over time, it evolves to become something bigger than the personal. The quotidian, at the end of the day, becomes banal: June remembers her Tamil lover, now living in London, bringing the narrator to note that "love is love. It wears off. At the end there is a certain wonder at how you had become caught up in the domestic drama of it all" (115). For Sydney, on the other hand, sex means a great deal; she is "June's first lover without a cause" (133). Sydney is described as the lover who "wants to risk all of it, like now" for June (30). Her love of June is "simple" (173), sexual, and bold, but not romantic in the ways that June, perhaps nostalgically, expects.

Late in The Promise of Happiness, Sara Ahmed returns to the question of love. Her analysis of happiness has shown that normativity is generated through invocations of happiness, particularly through oft-repeated scripts like the everyday statement "I just want you to be happy", through which a speaker invokes a particular concept of happiness. This happiness, Ahmed argues, is based upon normativities that exclude feminist, queer, and migrant bodies, inter alia. It is a happiness that is used in order to control others. Unhappy bodies, Ahmed continues, are problematic and are frequently read as being at fault, as lying outside of the rightful quest for happiness. It is in this context that love resurfaces: Ahmed argues that the politics of marginalized bodies involve veering from the script or path of happiness. And, moreover, "if to challenge the right to happiness is to deviate from the straight 
path, then political movements involve sharing deviation with others. There is joy, wonder, hope, and love in sharing deviation. If to share deviation is to share what causes unhappiness, even joy, wonder, hope, and love are ways of living with rather than living without unhappiness" (196; italics in original). The invocation of love is important in this passage: the statement appears at first to be a contradiction to her earlier distrust. However, Ahmed suggests that we need to be specific about what it is that we mean by love. She sees and attends to the risk of love; similarly, she distances it from happiness and reclaims it from hetero-patriarchal racial normativity. The scripts of love, instead, must be multiple.

What, then, is the final articulation of love that Brand leaves us with in Love Enough? June and Sydney, after a night of sex, wake up and begin arguing, first about a proposed pipeline project, and then about their relationship. The argument revolves around the definition of love. Sydney tells June that "you think it's deep, that's why you can't do it" (173), while June feels like "all the people in [the] world had agreed on a lethal definition of love. It was full of rapture and betrayal and intrigue and she was no good at that" (173). The definition of love opens up, June accusing Sydney of being "superficial" (174) in her conception, while Sydney accuses June of obfuscation. June confronts Sydney for her failure to fulfill the request for an embrace per day and a kindness per week, while Sydney says to June that she "collect[s] sadness" (178). The conversation falls to silence; "it is the silence of ending" (179) and, possibly, the end of their relationship. And yet, Sydney realizes as she soothes June, "someone has to" collect sadness (179). Their incompatible visions of love may not, in the end, signal an impasse. The book ends with the following: "[t]here is nothing universal or timeless about this love business, Sydney now suspects for the first time. It is hard if you really want to do it right" (180).

The forms of love that we witness in Love Enough, I contend, offer a possible glimpse of post-human love, and a way to think through the trouble of being labeled more or less human. As such, the novel is evidence of a fiction of globality produced in Canada that is a response to a troubled world. The question of post-human love might demonstrate what is at stake when some bodies are labeled monstrous, in other words. When Sydney and June wrestle with their relationship, they are, in part, wrestling with something akin to Michael Warner's worry in The Trouble with Normal (1999) that queer love is rife for being appropriated back into liberal visions of normalcy (and the human) via marriage scripts and the narratives of the "good life" against which thinkers of affect like Lauren Berlant write. For there to be love enough, in other words, to counter the toxins of neoliberalism is insufficient: it must not only exist in adequate quantities, to extend Brand's metaphor, but also in the right formula. The formula for love that has been promoted thus far may well be part of the toxic mix -and hence be dysfunctional for Brand's struggling lovers. Post-human love, on the other hand, might pick up from queer studies and affect theory in order to push back at the scripts of recognition that delimit and constrain the non-normative body. In Gender Failure, the resolution that comes, limited though it might be, arrives when Ivan E. Coyote and Rae Spoon both learn, slowly, and through many acts of suffering, that their trans bodies are bodies whose worth is intrinsic, rather than determined by the world around them, the world that 
deems them to be only more or less human. In that dynamic, I wonder anew, and to conclude: can there be such a thing as post-human love? I hope that there can be, and that we might begin to usher it into the world.

Reviews sent to author: 3 December 2018

Revised paper accepted for publication: 30 December 2018 


\section{WORKS CITED}

Ahmed, Sara. The Cultural Politics of Emotion. New York: Routledge, 2004. Print.

Ahmed, Sara. The Promise of Happiness. Durham, NC: Duke UP, 2010. Print.

Badiou, Alain with Nicolas Truong. In Praise of Love. Translated by Peter Bush. New York: New P, 2012. Print.

Barrett, Paul. Blackening Canada: Diaspora, Race, Multiculturalism. Toronto: U Toronto P, 2015. Print.

Berlant, Lauren. Cruel Optimism. Durham, NC: Duke UP, 2011. Print.

Berlant, Lauren. Desire/Love. New York: Punctum, 2012. Print.

Braidotti, Rosi. The Posthuman. London: Polity, 2013. Print.

Brand, Dionne. Love Enough. Toronto: Knopf, 2014. Print.

ButLer, Judith. Giving an Account of Oneself. New York: Fordham UP, 2005.

Connolly, William E. The Fragility of Things: Self-Organizing Processes, Neoliberal Fantasies, and Democratic Activism. Durham, NC: Duke UP, 2013. Print.

Coulthard, Glen. Red Skin, White Masks. Minneapolis: Minnesota UP, 2014. Print.

Coupland, Douglas. Player One. Toronto: Anansi, 2010. Print.

Coyote, Ivan E., and Rae Spoon. Gender Failure. Vancouver: Arsenal, 2014. Print.

Dobson, Kit. Transnational Canadas: Anglo-Canadian Literature and Globalization. Waterloo, ON: Wilfrid Laurier UP, 2009. Print.

Dobson, Kit. "Dystopia Now: Examining the Rachels in Player One and Automaton Biographies." Blast, Corrupt, Dismantle, Erase: Contemporary North American Dystopian Literature. Ed. by Brett Josef Grubisic, Tara Lee, and Gisèle M. Baxter. Waterloo, ON: Wilfrid Laurier UP, 2014. 393-408. Print.

Doвson, Kit. "Neoliberalism, the Novel, and the Limits of the Human: Rawi Hage's Cockroach." Textual Practice 29.2 (2015): 255-271. Print.

Doвson, Kit. "Untold Bodies: Failing Gender in Canada's Past and Future." Untold Stories of the Past 150 Years. Ed. by Linda Morra, Louis-Georges Harvey, and Sarah Henzi. Waterloo, ON: Wilfrid Laurier UP, under review. Print.

Fanon, Frantz. Black Skin, White Masks. Translated by Charles Lam Markmann. New York: Grove P, 1967. Print.

García Zarranz, Libe. TransCanadian Feminist Fictions: New Cross-Border Ethics. Montreal: McGill-Queen's UP, 2017. Print.

Hardt, Michael. The Procedures of Love. Berlin: Hatje Cantz, 2012. Print.

Ноoкs, bell. All About Love: New Visions. New York: HarperCollins, 2000. Print.

Irigaray, Luce. The Way of Love. Translated by Heidi Bostic and Stephen Pluhàcek. New York: Continuum, 2002. Print.

Justice, Daniel Heath. Why Indigenous Literatures Matter. Waterloo, ON: Wilfrid Laurier UP, 2018. Print.

LaI, Larissa. Automaton Biographies. Vancouver: Arsenal, 2009. Print. 
Maracle, Lee. Talking to the Diaspora. Winnipeg: ARP, 2015. Print.

Nussbaum, Martha. Political Emotions: Why Love Matters for Justice. Cambridge, MA: Belknap P, 2015. Print.

Povinelli, Elizabeth. Economies of Abandonment: Social Belonging and Endurance in Late Liberalism. Durham, NC: Duke UP, 2011. Print.

Warner, Michael. The Trouble with Normal: Sex, Politics, and the Ethics of Queer Life. New York: Free Press, 1999. Print. 